\title{
Diet and microhabitat use by two Hylodinae species (Anura, Cycloramphidae) living in sympatry and syntopy in a Brazilian Atlantic Rainforest area
}

\author{
Mauricio Almeida-Gomes ${ }^{1,2}$, Fábio H. Hatano ${ }^{1}$, Monique Van Sluys ${ }^{1} \&$ Carlos F. D. Rocha ${ }^{1}$ \\ 1. Departamento de Ecologia, Instituto de Biologia Roberto Alcântara Gomes, Universidade do Estado do Rio de Janeiro, Rua São \\ Fransisco Xavier, 524, 20550-013 Rio de Janeiro, RJ, Brasil. \\ 2. Corresponding author. (gomesuerj@yahoo.com.br)
}

\begin{abstract}
We analyzed the diet and microhabitat use for two Hylodinae anurans (Cycloramphidae), Hylodes phyllodes Heyer \& Cocroft, 1986 and Crossodactylus gaudichaudii Duméril \& Bibron, 1841, living in sympatry at an Atlantic Rainforest area of Ilha Grande, in southeastern Brazil. The two species live syntopically at some rocky streams. The two species differed strongly in microhabitat use. Hylodes phyllodes occurred mainly on rocks, whereas C. gaudichaudii was observed mostly on the water. Regarding diet, coleopterans, hymenopterans (ants), and larvae were the most important prey item consumed by both species. Data suggest that microhabitat use appears to be an important parameter differentiating these frogs with respect to general resource utilization.
\end{abstract}

KEYWORDS. Anuran, sympatry, syntopy, Atlantic Rainforest, Ilha Grande.

RESUMO. Dieta e uso do microhabitat em duas espécies de Hylodinae (Anura, Cycloramphidae) vivendo em simpatria e sintopia em uma área de Mata Atlântica. Nós analisamos a dieta e o uso do microhabitat em duas espécies de anuros da subfamília Hylodinae (Cycloramphidae), Hylodes phyllodes Heyer \& Cocroft, 1986 e Crossodactylus gaudichaudii Duméril \& Bibron, 1841, que vivem em simpatria em uma área de Mata Atlântica na Ilha Grande, na região sudeste do Brasil. As duas espécies vivem sintopicamente em alguns riachos pedregosos. As duas espécies diferiram fortemente no uso do microhabitat. Hylodes phyllodes ocorreu principalmente sobre pedras, enquanto $C$. gaudichaudii foi observado na maioria das vezes dentro d'água. Com relação à dieta, coleópteros, himenópteros (formigas), e larvas foram as presas mais consumidas por ambas as espécies. Os dados sugerem que o uso do microhabitat parece ser um importante parâmetro diferenciando esses anuros com respeito a utilização de recursos.

PALAVRAS-CHAVE. Anuro, simpatria, sintopia, Mata Atlântica, Ilha Grande.

For sympatric species, the study of trophic relationships is fundamental to understand the magnitude of interactions between them (DuRÉ \& KeHr, 2001, 2004). For anuran amphibians, as for other organisms, differences in resource utilization may facilitate the coexistence of species occurring in sympatry and syntopy (e.g. Duellman,1978; Van Sluys \& Rocha, 1998; DurÉ \& KEHR, 2001, 2004).

At the Atlantic Rainforest of Ilha Grande, a large island located in southern coast of the state of Rio de Janeiro, Brazil, two frog species of the cycloramphid subfamily Hylodinae (sensu LYNCH, 1971), Crossodactylus gaudichaudii Duméril \& Bibron, 1841 and Hylodes phyllodes Heyer \& Cocroft, 1986 occur in syntopy in some localities. Both species are diurnal and endemic to the Atlantic Forest of the states of Rio de Janeiro and São Paulo, in southeastern Brazil (RochA et al., 1997; Frost, 2004). Crossodactylus gaudichaudii and $H$. phyllodes are generally found associated to streams inside the forest (HEYER \& COCROFT, 1986; IZECKSOHN \& Carvalho-e-Silva, 2001; Hatano et al., 2002).

In the present study, we investigate the patterns of resource utilization (food and microhabitat) in $C$. gaudichaudii and $H$. phyllodes and establish comparisons between the two species.

\section{MATERIAL AND METHODS}

Study area. Data were gathered from April 1996 to March 2004 in the Atlantic Rainforest of Ilha Grande $\left(23^{\circ} 11^{\prime} \mathrm{S}, 44^{\circ} 12^{\prime} \mathrm{W}\right)$. The forest exhibits different levels of regeneration from disturbances caused by human activities in the last centuries which ceased with the transformation of the area into a State Park (ARAúJo \& OLIVEIRA, 1988). Annual rainfall in the area is about 2,200 $\mathrm{mm}$ and mean annual temperature is about $22.5^{\circ} \mathrm{C}$ (data obtained from Estação Metereológica, Central Nuclear de Angra dos Reis, Rio de Janeiro).

Collecting methods and analysis. Field observations were performed along three streams in which $C$. gaudichaudii and $H$. phyllodes occur syntopically. To record spatial utilization by each species, monthly transects along the streams were performed, from June 2002 to January 2004. During transects, the microhabitat types where individuals of each species were sighted were recorded according to the following categories: 1) partially immersed in water; 2) on humid soil; 3) on rock; 4) on tree root; 5) in rock crevice, and 6) on leaf-litter.

For analysis of the trophic niche we used $51 \mathrm{H}$. phyllodes and 21 C. gaudichaudii that had been collected for studies of reproductive traits and endoparasite faunas. The individuals of $H$. phyllodes were collected from April 1996 to April 2003, while the $C$. gaudichaudii were collected from April 1999 to February 2003. Those collections were done in a different stream from those where the observations on microhabitat use were conducted. The individuals were euthanized in 50\% alcohol and fixed in $10 \%$ formaline. The frogs were measured in their snout-vent length (SVL) and in their 
mouth width, with a caliper (to the nearest $0.1 \mathrm{~mm}$ ). The individuals were dissected and had their stomach contents examined under stereomicroscopes. The frog specimens were deposited at the herpetological collection of the Museu Nacional, Rio de Janeiro (Hylodes phyllodes: MNRJ 35191-35222 and MNRJ 35244-35262; Crossodactylus gaudichaudii: MNRJ 40604-40606 and MNRJ 41746-41763). We analyzed the diet composition in terms of number, volume and frequency of occurrence of each prey type. All prey items found were identified to Order, and had their length and width measured with a calliper (to the nearest $0.1 \mathrm{~mm}$ ). Prey volume was estimated for each prey item using the formula for an ovoidspheroid: $\mathrm{V}=4 / 3 \pi(\mathrm{L} / 2)(\mathrm{W} / 2)^{2}$, where $\mathrm{L}$ is the length and $\mathrm{W}$ the width of a given prey item (Dunham, 1983). This formula has been used in other recent studies of frogs diets (Duré \& Kehr, 2004; Maneyro et al., 2004). For each prey category, we also calculated an index of importance $\left(\mathrm{I}_{\mathrm{x}}\right)$ (Powell et al., 1990) which represents the sum of the proportions of the number, volume, and frequency of occurrence of each prey in the diet divided by three. In order to evaluate the effect of frog mouth width on mean prey length and volume we used simple regression analyses (ZAR, 1999). The differences between the two species in body size and mouth width, and in mean prey length and volume were tested by one-way analysis of variance (ANOVA) (ZAR, 1999). For both frog species, the mean length and volume of prey consumed were calculated only for individuals containing more than one item in their stomachs $(H$. phyllodes, $\mathrm{N}=39 ; C$. gaudichaudii, $\mathrm{N}=16$ ). We tested for the normality of the data distribution, and when the data did not fit a normal distribution we used a non-parametric test.

\section{RESULTS}

The two species differed in patterns of microhabitat use. Hylodes phyllodes occurred mainly on rocks, whereas $C$. gaudichaudii was observed mostly in the water (Fig. 1)

Of the individuals analyzed for diet, 48 Hylodes phyllodes $(94.1 \%)$ and 18 Crossodactylus gaudichaudii $(85.7 \%)$ had food in their stomachs. Diet of both species was composed of various arthropod groups (Tab. I). Coleopterans, hymenopterans (ants), and larvae were the most important prey item consumed by both species (Tab. I). As the mean prey volumes did not follow a normal distribution for $H$. phyllodes (Kolmogorov-Smirnov:

Table I. Number $(\mathrm{N})$, volume $\left(\mathrm{V}\right.$; mm3), frequency of occurrence $(\mathrm{F})$, and index of importance $\left(\mathrm{I}_{\mathrm{x}}\right)$ of prey consumed by Hylodes phyllodes $(\mathrm{N}=48)$ and Crossodactylus gaudichaudii $(\mathrm{N}=18)$ at the Atlantic Rainforest of Ilha Grande, Brazil (U.A.R., unidentified arthropod remains).

\begin{tabular}{|c|c|c|c|c|c|c|c|c|}
\hline \multirow[b]{2}{*}{ Prey category } & \multicolumn{4}{|c|}{ Hylodes phyllodes $(\mathrm{N}=48)$} & \multicolumn{4}{|c|}{ Crossodactylus gaudichaudii $(\mathrm{N}=18)$} \\
\hline & $\mathrm{N}(\%)$ & $\mathrm{V}(\%)$ & $\mathrm{F}(\%)$ & $\mathrm{Ix}$ & $\mathrm{N}(\%)$ & $\mathrm{V}(\%)$ & $\mathrm{F}(\%)$ & Ix \\
\hline \multicolumn{9}{|l|}{ INSECTA } \\
\hline Coleoptera & $26(11.8)$ & $448.5(14.6)$ & $21(41.2)$ & 0.225 & $13(14.0)$ & $144.9(6.8)$ & $9(50.0)$ & 0.212 \\
\hline Hymenoptera (ants) & $32(14.5)$ & $88.7(2.9)$ & $19(37.2)$ & 0.182 & $22(23.6)$ & $104.5(4.9)$ & $14(77.7)$ & 0.291 \\
\hline Hymenoptera (non-ants) & $7(3.2)$ & $18.6(0.6)$ & $6(11.8)$ & 0.052 & $7(7.5)$ & $450.3(21.2)$ & $4(22.2)$ & 0.159 \\
\hline Orthoptera & $7(3.2)$ & $212.6(6.9)$ & $5(9.8)$ & 0.066 & $2(2.1)$ & $24.4(1.1)$ & $2(11.1)$ & 0.127 \\
\hline Diptera & $14(6.4)$ & $91.0(3.0)$ & $10(19.6)$ & 0.096 & $8(8.6)$ & 39.7 (1.9) & $3(16.6)$ & 0.082 \\
\hline Hemiptera & $9(4.1)$ & $70.7(2.3)$ & $7(13.7)$ & 0.067 & $3(3.2)$ & $99(4.7)$ & $3(16.6)$ & 0.074 \\
\hline Homoptera & $7(3.2)$ & $135.0(4.4)$ & $6(11.8)$ & 0.064 & - & - & - & - \\
\hline Isoptera & $2(0.9)$ & $10.9(0.3)$ & $2(3.9)$ & 0.017 & - & - & - & - \\
\hline Odonata & - & - & - & - & $2(2.1)$ & $51.2(2.4)$ & $2(11.1)$ & 0.046 \\
\hline Blattaria & $1(0.4)$ & $11.3(0.4)$ & $1(2.0)$ & - & $4(4.3)$ & $462.5(21.8)$ & $3(16.6)$ & 0.134 \\
\hline Psocoptera & - & - & - & - & $2(2.1)$ & $2.8(0.1)$ & $1(5.5)$ & 0.023 \\
\hline Phasmida & - & - & - & - & $1(1.0)$ & $6.5(0.3)$ & $1(5.5)$ & 0.020 \\
\hline Collembola & - & - & - & - & $1(1.0)$ & $3.2(0.2)$ & $1(5.5)$ & 0.020 \\
\hline Larvae & $86(39.1)$ & $1234.5(40.3)$ & $23(45.1)$ & 0.415 & $15(16.1)$ & $230.7(10.8)$ & $7(38.8)$ & 0.193 \\
\hline \multicolumn{9}{|l|}{ ARACHNIDA } \\
\hline Aranae & $16(7.3)$ & $155.9(5.1)$ & $14(27.4)$ & 0.132 & $8(8.6)$ & $107.1(5.0)$ & $6(33.3)$ & 0.141 \\
\hline Acari & $1(0.4)$ & $2.3(0.1)$ & $1(2.0)$ & 0.008 & - & - & - & - \\
\hline Opiliones & - & - & - & - & $1(1.0)$ & $2.4(0.1)$ & $1(5.5)$ & 0.019 \\
\hline Pseudoscorpiones & - & - & - & - & $1(1.0)$ & $0.6(0.1)$ & $1(5.5)$ & 0.019 \\
\hline \multicolumn{9}{|l|}{ CRUSTACEA } \\
\hline Isopoda & $8(3.6)$ & $89.2(2.9)$ & $8(15.7)$ & 0.074 & $2(2.1)$ & $8.9(0.4)$ & $2(11.1)$ & 0.040 \\
\hline \multicolumn{9}{|l|}{ MOLLUSCA } \\
\hline Gastropoda & - & - & - & - & $1(1.0)$ & $3.8(0.2)$ & $1(5.5)$ & 0.020 \\
\hline \multicolumn{9}{|l|}{ CHILOPODA } \\
\hline Chilopoda & $4(1.8)$ & $8.5(0.3)$ & $4(7.8)$ & 0.033 & - & - & - & - \\
\hline U.A.R. & & $482.7(15.8)$ & & & & $381.6(18.0)$ & & \\
\hline TOTAL & 220 & 3060.4 & & & 93 & 2124 & & \\
\hline
\end{tabular}




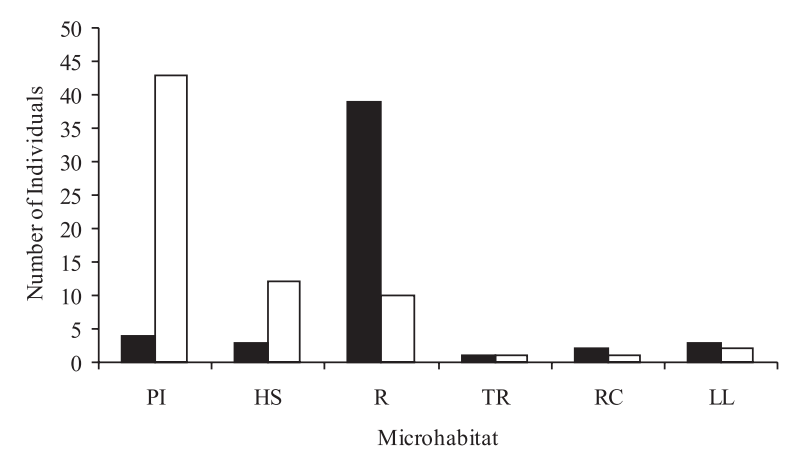

Fig. 1. Number of individuals of Hylodes phyllodes $(\mathrm{N}=52)$ (black bars) and Crossodactylus gaudichaudii $(\mathrm{N}=69)$ (white bars) using each microhabitat category at the Atlantic Rainforest of Ilha Grande, Brazil (HS, on humid soil; LL, on leaf-litter; PI, partially immersed in water; $\mathrm{R}$, on rock; $\mathrm{RC}$, in rock crevice; TR, on tree root).

Dmax $=0.235, \mathrm{P}<0.001)$ and for $C$. gaudichaudii $(\mathrm{KS}$ : Dmax $=0.333, \mathrm{P}<0.001)$, the values were log-transformed before performing regression analyses and ANOVAs.

In body size, $H$. phyllodes $=33.9 \pm 0.45 \mathrm{~mm}$ (range 19.9-37.9 mm; $\mathrm{N}=51$ ) was significantly larger than $C$. gaudichaudii $=28.9 \pm 0.40 \mathrm{~mm}$ (range 26.0-33.1 $\mathrm{mm} ; \mathrm{N}=$ 21) (ANOVA, $F_{1,70}=44.11 ; P<0.001$ ). However, the two species did not differ significantly in mouth width $H . p$. = $10.7 \pm 0.14 \mathrm{~mm}($ range 6.4-12.1 mm, N=51);C. g. $=10.3 \pm$ $0.1 \mathrm{~mm}$ (range 9.2-12.1 mm, $\mathrm{N}=21$ ) (ANOVA: $\mathrm{F}_{1,70}=1.99$, $\mathrm{P}=0.16)$, nor in mean prey length $H . p .=5.2 \pm 0.38 \mathrm{~mm}$ (range 1.7-11.6 mm; $\mathrm{N}=39$ ) and $C . g .=4.4 \pm 0.1 \mathrm{~mm}$ (range 1.6-8.0 mm; $\mathrm{N}=16$ ) (ANOVA, $\mathrm{F}_{1,53}=1.423 ; \mathrm{P}=0.238$ ) or mean prey volume $H . p .=15.8 \pm 2.9 \mathrm{~mm}$ (range $0.75-82.9$ $\mathrm{mm}, \mathrm{N}=39 ;$ C. $g .=25.5 \pm 9.8 \mathrm{~mm}$ (range $1.4-166.1 \mathrm{~mm}, \mathrm{~N}$ =16) (ANOVA: $\left.F_{1,53}=1.46, P=0.23\right)$. Prey size was not correlated to mouth width, either in $H$. phyllodes (prey length: $\mathrm{R}^{2}=0.04, \mathrm{~F}_{1,37}=1.44, \mathrm{P}=0.24$; prey volume: $\mathrm{R}^{2}=$ $0.02, \mathrm{~F}_{1,37}=0.85, \mathrm{P}=0.36$ ) or in $C$. gaudichaudii (prey length: $\mathrm{R}^{2}=0.03 ; \mathrm{F}_{1,14}=0.40, \mathrm{P}=0.54$; prey volume: $\mathrm{R}^{2}=$ $0.02, \mathrm{~F}_{1,14}=0.34, \mathrm{P}=0.57$ ). As ants are small items and were found in high proportions in the diet of both species, we remade the analyses excluding ants. Still, there was no influence of mouth size on neither size nor volume (log-transformed) of prey consumed by $C$. gaudichaudii (prey length: $\mathrm{R}^{2}=0.054 ; \mathrm{F}_{1,8}=0.454, \mathrm{P}=0.519$; prey volume: $\left.\mathrm{R}^{2}=0.005, \mathrm{~F}_{1,8}=0.043, \mathrm{P}=0.840\right)$ and $H$. phyllodes (prey length: $\mathrm{R}^{2}=0.073, \mathrm{~F}_{1,20}=1.577, \mathrm{P}=0.224$; prey volume: $\left.\mathrm{R}^{2}=0.126, \mathrm{~F}_{1,20}=2.887, \mathrm{P}=0.105\right)$.

\section{DISCUSSION}

Our data indicate that, although living in the same stream, the two species differed consistently in their use of microhabitats. Apart from differences in microhabitat preferences, the data suggest that $C$. gaudichaudii uses the habitat horizontally, whereas $H$. phyllodes uses the habitat more vertically. Males of $H$. phyllodes use rocks as calling sites and, when disturbed or scared by an observer, tend to seek refuge inside rock crevices, usually above the water level (Hatano et al., 2002). As for $C$. gaudichaudii, it appears to be more directly associated to the water. They are usually found partially immersed and do not leave the water even after detecting the presence of an observer. Also, when supposedly in danger, individuals of $C$. gaudichaudii tend to dive and remain motionless at the bottom of the stream (IZECKSOHN \& CARVAlHO-E-Silva, 2001; pers. obs.).

Both species fed exclusively on arthropods. Although the individuals of the two species have not been collected simultaneously, our data suggest that they have similar diets, with insect larvae, coleopterans and ants being important items for both species. The similarity in the diet of the two frogs is not surprising, considering that they are sympatric and syntopic (thus being exposed to a potentially similar prey spectrum) and have similar width of mouth. In other studies with sympatric pairs of anuran species, in other regions of South America, interspecific differences in mouth width were reflected in the sizes of prey consumed (e.g. VAN SLUYS \& RochA, 1998; Duré \& KeHr, 2001). Since amphibians usually ingest their prey whole, mouth dimensions tend to restrict the upper limit of prey size they can consume, which is generally reflected by a relationship between mouth dimensions and prey dimensions (e.g. DuELlman \& TRUEB, 1986; LiMA \& MOREIRA, 1993; VAN SLUYS \& RochA, 1998; DurÉ \& KeHR, 2001; VAN SLuYs et al., 2001), which was not observed in the present study. The high consumption of ants, which are preys of small size and little size variation (which reduces the overall variation in prey size in the frogs' diets) may have contributed for the lack of significant relationship between mouth width and prey dimensions for the two species. We cannot tell to which extent the lack of correlation between prey size and mouth width of these two stream-dwelling hylodines may be related to specific characteristics of their foraging patterns, which are currently unknown.

For species living in syntopy it is believed that coexistence may be favored if they differ consistently in resource utilization (SCHOENER, 1970, 1974). In the case of $H$. phyllodes and $C$. gaudichaudii, our data suggest that differences in microhabitat utilization constitute an important factor favoring a coexistence of these species in forest streams.

Acknowledgements. This study is part of the results of the "Ecology, Conservation and Management of Southeastern Brazilian Ecosystems Program" and of the "Southeastern Brazilian Vertebrate Ecology Project (Vertebrate Ecology Laboratory)" of the Departamento de Ecologia, Instituto de Biologia, Universidade do Estado do Rio de Janeiro. We thank the Centro de Estudos Ambientais e Desenvolvimento Sustentável (CEADS/UERJ) for local support and for making many facilities available. We also thank the Sub-Reitoria de Pós-Graduação e Pesquisa (SR-2/UERJ) for Institutional support and for many facilities along the study. Davor Vrcibradic kindly read the manuscript offering helpful suggestions. During the development of this study C. F.D.R. (Processes No.307 653/2003-0 and 477981/2003-8) and MVS (Process No.302405/02-0) received Research Grants of the Conselho Nacional de Desenvolvimento Científico e Tecnológico - CNPq. M.A.G. and F.H.H. received Graduate Fellowship from Comissão de Aperfeiçoamento de Pessoal de Nível Superior - CAPES.

\section{REFERENCES}

Araújo, D. \& Oliveira, R. 1988. Reserva Biológica Estadual da Praia do Sul (Ilha Grande, Rio de Janeiro). Lista preliminar da 
flora Acta Botanica Brasilica 1:83-94.

Duellman, W. E. 1978. The biology of an equatorial herpetofauna of Amazonian Ecuador. Miscellaneous Publications of the University of Kansas Museum of Natural History 65:1-352.

Duellman, W. E. \& Trueb, L. 1986. Biology of amphibians. New York, McGraw-Hill. 670p.

Dunham, A. E. 1983. Realized niche overlap, resource abundance and intensity of interspecific competition. In: HueY, R. D.; Pianka, E. R. \& Schoener, T. W. eds. Lizards ecology. Cambridge, Harvard University. p.261-280.

Duré, M. I. \& KeHr, A. I. 2001. Differential exploitation of trophic resources by two pseudid frogs from Corrientes, Argentina. Journal of Herpetology 35:340-343.

_- 2004. Influence of microhabitat on the trophic ecology of two leptodactylids from northeastern Argentina. Herpetologica 60(3):295-303.

Frost, D. R. 2004. Amphibian species of the World: an online reference. Version 3.0. Available at: <http:// research.amnh.org/herpetology/amphibia/index.php>. Access on: 22.08 .2004

Hatano, F. H.; Rocha, C. F. D. \& Van Sluys, M. 2002. Environmental factors affecting calling activity of a tropical diurnal frog (Hylodes phyllodes: Leptodactylidae). Journal of Herpetolology 36(2):314-318

Heyer, W. R. \& Cocroft, R. B. 1986. Descriptions of two new species of Hylodes from the Atlantic forests of Brazil (Amphibia: Leptodactylidae). Proceedings of the Biological Society of Washington 99:100-109.

Izecksohn, E. \& Carvalho-e-Silva, S. P. 2001. Anfíbios do município do Rio de Janeiro. Rio de Janeiro, Editora UFRJ. 148p.
Lima, A. P. \& Moreira, G. 1993. Effects of prey size and foraging mode on the ontogenetic change in feeding niche of Colostethus stepheni (Anura: Dendrobatidae). Oecologia 95:93-102.

LyNCH, J. D. 1971. Evolutionary relationships, osteology, and zoogeography of leptodactyloid frogs. Miscellaneous Publication of the University of Kansas Museum of Natural History (53): 1-238

Maneyro, R.; Naya, D. E.; Rosa, I.; Canavero, A. \& Camargo, A 2004. Diet of the south American frog Leptodactylus ocellatus (Anura: Leptodactylidae) in Uruguay. Iheringia, Série Zoologia, 94(1):57-61.

Powell, R.; Parmerlee, J. S.; Rice, M. A. \& Smith, D. D. 1990. Ecological observations on Hemidactylus brooki haitianus Meerwarth (Sauria: Gekkonidae) from Hispaniola. Caribbean Journal of Science 26:67-70.

Rocha, C. F. D.; Van Sluys, M. \& Hatano, F. H. 1997. Hylodes phyllodes (Leaf frog): geographic distribution. Herpetological Review 28(4): 208 .

Schoener, T. W. 1970. Non-synchronous spatial overlap of lizards in patchy habitats. Ecology 51:408-418.

1974. Resource partitioning in ecological communities. Science 185:27-38.

Van Sluys, M. \& Rocha, C. F. D. 1998. Feeding habits and microhabitat utilization by two syntopic Brazilian Amazonian frogs (Hyla minuta and Pseudopaludicula sp. Revista Brasileira de Biologia 58(4):559-562.

Van Sluys, M.; Rocha, C. F. D. \& Souza, M. B. 2001. Ecology of the Leptodactylid litter frog Zachaenus parvulus in Atlantic Rainforest of southeastern Brazil. Journal of Herpetolology 35(2):322-325

ZAR, J. H. 1999. Biostatistical analysis. 4ed. Upper Saddle River, Prentice Hall. 663p

Recebido em abril de 2005. Aceito em agosto de 2006. ISSN 0073-4721

Artigo disponível em: www.scielo.br/isz 